\title{
Effect of CROP Residues Applied Isolated or in Combination on the Germination and Seedling Growth of Horse Purslane (Trianthema portulacastrum) ${ }^{1}$
}

\author{
Efeito de Resíduos Vegetais Aplicados Isolados ou em Associação na Germinacão e Crescimento \\ de Plântulas de (Trianthema portulacastrum)
}

KHALIQ, A. ${ }^{*}$, MATLOOB, A. ${ }^{2}$, FAROOQ, M. $^{2}$, MUSHTAQ, M.N. ${ }^{3}$ and KHAN, M.B. ${ }^{4}$

\begin{abstract}
Soil incorporation of crop residues can lead to weed suppression by posing allelopathic and physical effects. Allelopathic potential of the crops sorghum, sunflower, brassica applied as sole or in combination for horse purslane (Trianthema portulacastrum) suppression was evaluated in a pot investigation. Chopped crop residues alone and in combination were incorporated at $6 \mathrm{~g} \mathrm{~kg}^{-1}$ soil $\left(12 \mathrm{t} \mathrm{ha}^{-1}\right)$, and a weedy check was maintained. Germination traits time to start germination; time to $50 \%$ emergence, mean emergence time, emergence index and final germination percentage were negatively influenced by residue incorporation. Crop residues also exerted a pronounced negative influence on the shoot and root length of horse purslane. Significant suppression in leaf and root score and leaf area per plant was also observed. A combination of sorghum and sunflower residues accounted for maximum (71\%) seedling mortality. Soil incorporation of allelopathic crop residues can be employed for horse purslane management.
\end{abstract}

Keywords: residues, allelopathic, sorghum, sunflower, brassica, Trianthema portulacastrum, germination/seedling growth, suppression.

RESUMO - A incorporação de resíduos vegetais pode levar à supressão de plantas daninhas devido a efeitos físicos, químicos e alelopáticos. O efeito alelopático potencial de resíduos de sorgo, girassol e canola, aplicados isolados ou em combinação, foi avaliado em relação à germinação e crescimento inicial de beldroegas-cavalo (Trianthema portulacastrum) em experimento em vasos. Os residuos vegetais foram picados e incorporados no solo na quantidade de $6 \mathrm{~g} \mathrm{~kg}^{-1} \mathrm{de}$ solo, que é equivalente a $12 t$ ha ${ }^{-1}$; manteve-se também um tratamento sem residuos. Otempo para iniciar a germinação, tempo de emergência de 50\% (E50), tempo médio de emergência, índice de emergência e porcentagem final de germinação foram influenciados negativamente pela incorporação dos residuos. A palhada também exerceu forte influência negativa sobre o crescimento da parte aérea e comprimento radicular de beldroegas-cavalo. Também foi observada supressão significativa na contagem de folhas e raizes érea foliar. A combinação de residuos de sorgo e girassol causou a máxima mortalidade de plântulas, que foi de $71 \%$. A incorporação de resíduos vegetais de culturas pode ser utilizada para o manejo de beldroegas-cavalo.

Palavras-chave: alelopatia, canola, girassol, resíduos vegetais, sorgo, Trianthema portulacastrum.

\section{INTRODUCTION}

Horse purslane (Trianthema portulacastrum) is an annual indigenous plant of South Africa that is widely distributed in South East and West Asia, Africa and Tropical America. It is one of the problematic terrestrial weed by virtue of its competitiveness as a $\mathrm{C}_{4}$ species.

Recebido para publicação em 24.8.2010 e na forma revisada em 18.2.2011.

2 Department of Agronomy, University of Agriculture, Faisalabad, Pakistan; ${ }^{3}$ Graduate School of Life and Environmental Sciences, University of Tsukuba, Ibaraki, Japan, ${ }^{4}$ University College of Agriculture, Bahauddin Zakariya University, Multan, Pakistan, khaliquaf@gmail.com>. 
In Pakistan and India, it is among the most common weeds during summer season in the major field crops such as pulses, cotton, sugarcane, direct seeded rice and maize. Its infestation in cotton, maize and direct seeded rice especially in rainy season is a matter of great concern and could reduce crop yields by $32-60 \%$ (Baylan \& Malik, 1989). Horse purslane is also a major biological constraint to the large scale adoption of dry-direct-seeded rice in Pakistan and has endangered its sustainability. Significant losses in maize and peanut yield are also attributed to this weed (Gricher, 2008). Horse purslane has indeterminate growth habit which makes it highly competitive. Allelopathic growth inhibition of crop plants owing to horse purslane has also been reported (Sethi \& Mohnot, 1988). Enormous seeding capacity or very little dormancy allows the mature seed to germinate immediately thus producing multiple generations in the same season.

Horse purslane is easily killed by herbicides but once more it germinates with subsequent irrigations due to large seed bank. Although chemical weed control is effective and offers prompt solution to many of the weed related problems yet it has resulted in many herbicide resistance as well as environmental issues. These problems require the development and utilization of ecofriendly methods for horse purslane control. Allelopathy promises to be one such strategy which can be applied to manage many of the weed problems in agricultural systems.

Soil incorporation or surface application as mulch of allelopathic crop residues affects weed dynamics by reducing or delaying seed germination and establishment, suppressing individual plant growth resultantly contributed to overall decline in the density and vigor of the weed community (Gallandt et al., 1999). Allelopathic crop residues on decomposition produce a variety of phytotoxins, particularly the phenolics, in the soil causing side effects on the other plants (Nelson, 1996) and have potential to pose a chemical as well as a physical effect on the growth and development of subsequent crops and weeds (Purvis et al., 1985; Thorne et al., 1990), and can be managed for weed suppression (Weston, 1996). Phyototoxicity of dried sunflower residues and leaf powder has been reported (Batish et al., 2002). Incorporation of (in situ) whole sorghum plant or its various parts alone or mixed with each other was found to suppress weed growth in wheat (Cheema \& Khaliq, 2000). Brassica compestris also exhibited inhibitory effect on weed density in the following year due to decomposition of its residues. Tarahumara Indians in North Mexico use this crop for weed suppression (Chacon \& Gliessman, 1982; Norsworthy et al., 2005).

Although the exploitation of allelopathy as a natural weed management tool is eyecatching as an eco-friendly weed management approach yet contrary to bioassays, the suppression achieved under field conditions is often negligible (Bhowmik, 1992; Duke et al., 2001). Inderjit (2001) discussed the significance of soils in the expression of allelopathy that may be explained under field or pot experiments, and in terrestrial systems any bioassay without involving soil has no ecological relevance (Foy, 1999). In the absence of soil, any growth bioassay may have little or no significance. It is almost impossible to simulate exact field conditions in laboratory experiments, however an effort is made in present studies to simulate field conditions to the maximum extent mainly by using soil as a growing medium with the objectives of maintaining the physical, chemical, and biological soil factors of the natural setting (Schmidt \& Ley, 1999). Moreover, the pots were placed in a screen house under open environments.

Different pant species contain allelochemicals that vary in type and concentration. Release of allelochemicals by mixed residues can have a synergistic and/or additive effect on the target species. The present studies were carried out to investigate the suppressive effect of allelopathic sorghum, sunflower and brassica residues on germination dynamics and seedling growth of horse purslane.

\section{MATERIALS AND METHODS}

\section{Plant residues}

Field grown mature plants of sorghum (cv. JS-263), sunflower (Hysun-33) and brassica (Rainbow) were collected. These plants were 
chopped into $3-5 \mathrm{~cm}$ pieces with a fodder cutter and dried in an oven at $70{ }^{\circ} \mathrm{C}$ for $48 \mathrm{~h}$. Whole plant residues were mixed into the soil in situ.

\section{Bioassay}

Seed of horse purslane was cleaned manually to ensure physical purity. This seed was surface sterilized with water: bleach solution (10:1) for $15 \mathrm{~min}$ and rinsed four times with distilled water.

Plastic pots of $29 \times 18 \mathrm{~cm}$ and $10 \mathrm{~kg}$ capacity were filled with air dried, sieved, well mixed soil taken from the Agronomic Research Area. Soil belongs to Lyallpur soil series (Aridisol-fine-silty, mixed, hyperthermic Ustalfic, Haplargid in USDA classification and Haplic Yermosols in FAO classification). The $\mathrm{pH}$ of saturated soil paste was 7.6 and total soluble salts were $1.2 \mathrm{dS} \mathrm{m}^{-1}$. Organic matter, total nitrogen, available phosphorus and potassium were $0.71 \%, 0.062 \%, 13.1 \mathrm{ppm}$, and 179 ppm, respectively. Crop residues (sorghum, sunflower and brassica) alone and their combination in equal ratio were incorporated to have a total of $6 \mathrm{~g} \mathrm{~kg}^{-1}$ of soil $\left(12 \mathrm{t} \mathrm{ha}^{-1}\right)$. Pots without residue were included as control. Five days after incorporation of residues, thirty seeds of horse purslane were sown in each pot. The pots were placed in a screen house under natural solar radiations with an average temperature of $35 \pm 5{ }^{\circ} \mathrm{C}$, and were irrigated as necessary to keep the soil moist and avoid water stress. Experiment was repeated four times. The experiment was visited daily to record emergence count (AOSA, 1990) until a constant count was achieved. Time taken to $50 \%$ emergence $\left(E_{50}\right)$ was computed by following modified formula of Farooq et al. (2005):

$$
E_{50}=t_{i}+\frac{\left(\frac{N}{2}-n_{i}\right)\left(t_{j}-t_{i}\right)}{n_{j}-n_{i}}
$$

where $N$ is the final number of emerged seeds, and $n_{i}$ and $n_{\mathrm{j}}$ are the cumulative number of seeds emerged by adjacent counts at times $t_{i}$ and $t_{j}$ where $n_{i}<N / 2<n_{j}$.

Mean emergence time (MET) was calculated according to Ellis \& Robert (1981) as:

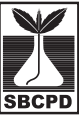

$$
\text { MET }=\frac{\sum D n}{\sum n} \text {, where } n \text { is the number of }
$$

seeds, which were emerged on day $D$ and $D$ is the number of days counted from the beginning of sprouting. Emergence index was calculated as described by AOSA (1983):

$E I=\frac{\text { No. of emerged seeds }}{\text { Days of first count }}+------+\frac{\text { No. of emerged seeds. }}{\text { Days of final count }}$

Root and shoot lengths were measured after $28 \mathrm{~d}$. Plants were uprooted after wetting in water and washing under tap and separated into roots and shoots from each pot. Number of leaves and secondary roots were counted manually and averaged. A sub-sample of $2 \mathrm{~g}$ leaves was used to measure the leaf area using a leaf area meter (Licor, Model LI-3000). Harvested plant material was oven-dried at $70{ }^{\circ} \mathrm{C}$ for $48 \mathrm{~h}$ and dry biomass of root and shoot was recorded. Total seedling biomass was taken as sum of root and shoot biomass. Seedling mortality was calculated as under:

Seedling mortality $(\%)=\frac{\text { No.of seedlings emerged }- \text { No. of seedling survived }}{\text { No. of seedlings emerged }} \times 100$

Total phenolics were determined as described by Randhir \& Shetty (2005) and are expressed as Gallic acid equivalents. Photosynthetic pigments (Chl.a and Chl.b) were extracted in in $80 \%$ ice cold acetone and read out at 663 and $645 \mathrm{~nm}$ wavelength in a UVspectrophotometer (UV-4000, ORI, Germany). These are expressed as $\mathrm{mg} \mathrm{g}^{-1}$ fresh leaf weight (Lichtenthaler \& Wellburn, 1987).

\section{Experimental design and statistical analysis}

Experimental pots were arranged in completely randomized design with three replicates. Data were analyzed following an analysis of variance and treatment means were separated using least significant differences (LSD) at $\mathrm{P} \leq 0.05$.

\section{RESULTS AND DISCUSSION}

Incorporation of allelopathic crop residues significantly suppressed the germination traits of horse purslane as compared with control (Table 1). Significant $(\mathrm{P} \leq 0.05)$ increase 
Table 1 - Influence of crop residues incorporated alone or in combination on germination dynamics of Trianthema portulacastrum

\begin{tabular}{|c|c|c|c|c|c|c|}
\hline \multicolumn{2}{|r|}{ Treatment } & \multirow{2}{*}{$\begin{array}{c}\begin{array}{c}\text { Time to start } \\
\text { germination } \\
\text { (days) }\end{array} \\
3.00 \mathrm{c}^{-1 /}\end{array}$} & \multirow{2}{*}{$\begin{array}{c}\begin{array}{c}\text { Final } \\
\text { germination } \\
(\%)\end{array} \\
87.78 \mathrm{a}\end{array}$} & \multirow{2}{*}{$\begin{array}{l}\text { Time to } 50 \% \\
\begin{array}{c}\text { emergence } \\
\text { (days) }\end{array} \\
3.80 \mathrm{e}\end{array}$} & \multirow{2}{*}{\begin{tabular}{|c|}
$\begin{array}{c}\text { Mean } \\
\text { emergence time } \\
\text { (days) }\end{array}$ \\
$5.97 \mathrm{~d}$ \\
\end{tabular}} & \multirow{2}{*}{$\begin{array}{c}\begin{array}{c}\text { Emergence } \\
\text { index }\end{array} \\
20.51 \mathrm{a}\end{array}$} \\
\hline $\mathrm{T}_{1}$ & Control & & & & & \\
\hline $\mathrm{T}_{2}$ & Sorghum residues incorporated at $6 \mathrm{~g} \mathrm{~kg}^{-1}$ soil & $3.33 \mathrm{bc}(11)^{2 /}$ & $58.89 \mathrm{~d}(-33)$ & $4.60 \mathrm{de}(21)$ & $6.69 \mathrm{bcd}(12)$ & $10.80 \mathrm{bc}(-47)$ \\
\hline $\mathrm{T}_{3}$ & Sunflower residues incorporated at $6 \mathrm{~g} \mathrm{~kg}^{-1}$ soil & $4.00 \mathrm{ab}(33)$ & $63.33 \mathrm{~d}(-28)$ & $5.08 \mathrm{~cd}(34)$ & $6.58 \mathrm{~cd}(10)$ & $10.18 \mathrm{bc}(-50)$ \\
\hline $\mathrm{T}_{4}$ & Brassica residues incorporated at $6 \mathrm{~g} \mathrm{~kg}^{-1}$ soil & $3.33 \mathrm{bc}(11)$ & 71.11 bcd (-19) & $5.14 \mathrm{bcd}(35)$ & $7.11 \mathrm{abc}(19)$ & $13.61 \mathrm{abc}(-34)$ \\
\hline $\mathrm{T}_{5}$ & $\begin{array}{l}\text { Sorghum }+ \text { sunflower residues each incorporated } \\
\text { at } 3 \mathrm{~g} \mathrm{~kg}^{-1} \text { soil }\end{array}$ & $3.33 \mathrm{bc}(11)$ & $58.89 \mathrm{~d}(33)$ & $5.19 \mathrm{bcd}(37)$ & $6.73 \mathrm{abcd}(13)$ & $15.12 \mathrm{ab}(-26)$ \\
\hline $\mathrm{T}_{6}$ & $\begin{array}{l}\text { Sorghum }+ \text { brassica residues each incorporated at } \\
3 \mathrm{~g} \mathrm{~kg}^{-1} \text { soil }\end{array}$ & $4.00 \mathrm{ab}(33)$ & $63.33 \mathrm{~d}(-28)$ & $5.75 \mathrm{abc}(51)$ & $7.05 \mathrm{abc}(18)$ & $11.70 \mathrm{bc}(-43)$ \\
\hline $\mathrm{T}_{7}$ & $\begin{array}{l}\text { Sunflower + brassica residues each incorporated } \\
\text { at } 3 \mathrm{~g} \mathrm{~kg}^{-1} \text { soil }\end{array}$ & $4.33 \mathrm{a}(44)$ & 71.11 bcd $(-19)$ & $6.05 \mathrm{ab}(59)$ & $7.53 \mathrm{a}(26)$ & 10.48 bc (-49) \\
\hline $\mathrm{T}_{8}$ & $\begin{array}{l}\text { Sorghum + sunflower }+ \text { brassica residues each } \\
\text { incorporated at } 2 \mathrm{~g} \mathrm{~kg}^{-1} \text { soil }^{1}\end{array}$ & $4.00 \mathrm{ab}(33)$ & $65.56 \mathrm{~cd}(-25)$ & $6.31 \mathrm{a}(66)$ & $7.43 \mathrm{ab}(24)$ & $7.98 \mathrm{c}(-61)$ \\
\hline & LSD & 0.71 & 13.73 & 0.95 & 0.85 & 6.99 \\
\hline
\end{tabular}

${ }^{1 /}$ Means with different letters differ significantly at $5 \%$ level of probability. ${ }^{2}$ Figures given in parenthesis show percent change over control.

in time to start germination and $\mathrm{E}_{50}$ was caused by incorporation of all residues which exerted more pronounced negative influence on $\mathrm{E}_{50}$ (ranging from 37 to $66 \%$ ) when used in combination than their sole application (21-35\%) over control. Incorporation of brassica residue either alone or in combination with rest of the residues, significantly prolonged mean emergence time (MET) over control. Final germination was suppressed by incorporation of all residues over control and suppression was similar where the sunflower and sorghum residues were applied at $6 \mathrm{~g} \mathrm{~kg}^{-1}$ soil. Interestingly, these two residues when applied in combination each at $3 \mathrm{~g} \mathrm{~kg}^{-1}$ soil or at $2 \mathrm{~g} \mathrm{~kg}^{-1}$ soil with brassica at $2 \mathrm{~g} \mathrm{~kg}^{-1}$ soil had similar level of germination inhibition of horse purslane. Emergence indices of horse purslane were significantly $(\mathrm{P} \leq 0.05)$ reduced with the incorporation of residues, and combination of residues was more inhibitory than their sole application. Germination dynamics were reflective of the suppressive effects of sorghum, sunflower and brassica residues. Sorghum (Cheema \& Khaliq, 2000), sunflower (Batish et al., 2002) and brassica (Chacon \& Gliessman, 1982) residues released phytochemicals during decomposition process (Thorne et al., 1990; Nelson, 1996) that were reported to be inhibitory to germination of a number of species (Purvis et al., 1985; Thorne et al., 1990; Cheema \& Khaliq, 2000; Batish, 2002; Norsworthy et al., 2005).

Seedling growth of horse purslane was also significantly $(P \leq 0.05)$ suppressed by the crop residues applied either alone or in combination (Table 2). The combination of sorghum, sunflower, brassica residues each at $2 \mathrm{~g} \mathrm{~kg}^{-1}$ soil, resulted in the highest inhibition of shoot (88\%) and root (59\%) lengths. Dry matter accumulation in shoot and root was also reduced. Sole application of brassica scored 86 and $91 \%$ reductions in shoot and root dry weight per seedling, respectively. It was statistical similar $(\mathrm{P} \leq 0.05)$ with other combinations of crop residues. Sorghum, sunflower, brassica residues exerted drastic influence on leaf score and suppressed it by 94\% (Table 2). Incorporation of crop residues also restricted lateral spread and proliferation of roots so that combination of sorghum and sunflower recorded $91 \%$ reduction in number of lateral roots per plant over control. Besides leaf score, leaf expansion in horse purslane was also reduced. Leaf area was reduced to higher extent with increasing number of crop residues. Sorghum and sunflower residue each at $3 \mathrm{~g} \mathrm{~kg}^{-1}$ soil caused $71 \%$ seedling mortality, which was at par with that $(64 \%)$ recorded for brassica residue alone at $6 \mathrm{~g} \mathrm{~kg}^{-1}$ 
soil (Table 2). The inhibition of horse purslane germination and growth may be attributed to the presence of several phytotoxins in sorghum such as Gallic acid, protocatechuic acid, syringic acid, vanillic acid, p-hydroxybenzoic acid, p-coumaric acid, benzoic acid, ferulic acid, m-coumaric acid, caffeic acids, phydroxybenzaldehyde and sorgoleone (Netzly \& Butler, 1986; Cheema et al., 2009). Several studies have identified allelochemicals from sorghum, their secretion mechanisms and genes regulating them and also confirmed sorghum allelopathic potential under natural and controlled conditions (Weston \& Duke, 2003; Weston, 2005). Sunflower contains allelochemicals viz. chlorogenic acid, isochlorogenic acid, á-naphthol, scopolin, and annuionones (Macias et al., 2002; Anjum \& Bajwa, 2005). The members of Brassicaceae family contain glucosinolates that upon hydrolysis yield isothicynates (JiménezOsornio \& Gliessman, 1987), and isoprenoids and benzoids (Tollsten \& Bergstrom, 1988) which exert allelopathic effects on germination and growth of other species (Norsworthy et al., 2005). Residues species varied in their severity against horse purslane eliciting brassica as the more toxic one. This shows the susceptibility of horse purslane to isothiocyanates. The variable influence of sorghum, sunflower and brassica residues on the horse purslane germination and seedling growth may be due to the type and concentration of allelochemicals present in these species (Xuan et al., 2005).

Horse purslane seedling grown in soil amended with allelopathic crop residues had reduced chlorophyll $\mathrm{a}$ and $\mathrm{b}$ in their leaves (Table 3). Total chlorophyll was reduced to

Table 2 - Influence of crop residues incorporated alone and in combination on seedling growth of T. portulacastrum

\begin{tabular}{|c|c|c|c|c|c|c|c|c|c|}
\hline \multirow[t]{2}{*}{ Treat. } & Shoot length & Root length & $\begin{array}{c}\text { Shoot dry } \\
\text { weight }\end{array}$ & $\begin{array}{c}\text { Root dry } \\
\text { weight }\end{array}$ & $\begin{array}{c}\text { Total dry } \\
\text { weight }\end{array}$ & \multirow{2}{*}{$\begin{array}{l}\text { Leaf score per } \\
\text { plant }\end{array}$} & \multirow{2}{*}{$\begin{array}{c}\text { Lateral roots } \\
\text { per plant }\end{array}$} & \multirow{2}{*}{$\begin{array}{c}\text { Leaf area } \\
\left(\mathrm{cm}^{2}\right)\end{array}$} & \multirow{2}{*}{$\begin{array}{c}\begin{array}{c}\text { Seedling } \\
\text { mortality }\end{array} \\
(\%)\end{array}$} \\
\hline & \multicolumn{2}{|c|}{$(\mathrm{cm})$} & \multicolumn{3}{|c|}{$\left(\mathrm{g}\right.$ seedling $\left.{ }^{-1}\right)$} & & & & \\
\hline $\mathrm{T}_{1}$ & $26.00 \mathrm{a}^{\mathrm{a}^{1 /}}$ & $9.62 \mathrm{a}$ & $2.27 \mathrm{a}$ & $0.16 \mathrm{a}$ & $2.42 \mathrm{a}$ & $182.21 \mathrm{a}$ & $13.19 \mathrm{a}$ & $58.74 \mathrm{a}$ & - \\
\hline $\mathrm{T}_{2}$ & $8.21 \mathrm{~d}(-68)^{\frac{2 /}{-}}$ & $5.22 \mathrm{~d}(-46)$ & $0.97 \mathrm{~b}(-57)$ & 0.03 c (-80) & $1.00 \mathrm{~b}(-59)$ & $52.57 \mathrm{c}(-71)$ & $4.05 \mathrm{bc}(-69)$ & $37.50 \mathrm{bc}(-36)$ & $43.86 \mathrm{bc}$ \\
\hline $\mathrm{T}_{3}$ & $9.21 \mathrm{~cd}(-65)$ & $7.07 \mathrm{~b}(-27)$ & $1.05 \mathrm{~b}(-54)$ & $0.09 \mathrm{~b}(-41)$ & $1.15 \mathrm{~b}(-53)$ & 54.15 c $(-70)$ & $3.06 \mathrm{~cd}(-77)$ & $36.25 \mathrm{c}(-38)$ & $56.70 \mathrm{abc}$ \\
\hline $\mathrm{T}_{4}$ & $9.94 b c(-62)$ & $5.99 \mathrm{~cd}(-38)$ & $0.31 \mathrm{c}(-86)$ & 0.02 c (-91) & 0.33 c (-86) & $48.42 \mathrm{c}(-73)$ & 3.85 bc $(-71)$ & 37.73 bc $(-36)$ & $64.18 \mathrm{ab}$ \\
\hline $\mathrm{T}_{5}$ & 5.47 e (-79) & $6.08 \mathrm{~cd}(-37)$ & $0.36 \mathrm{c}(-84)$ & $0.02 \mathrm{c}(-92)$ & $0.38 \mathrm{c}(-84)$ & $22.73 \mathrm{~d}(-88)$ & 1.15 e (-91) & $36.07 \mathrm{c}(-39)$ & $70.62 \mathrm{a}$ \\
\hline $\mathrm{T}_{6}$ & $11.31 \mathrm{~b}(-57)$ & $6.61 \mathrm{bc}(-31)$ & $0.79 \mathrm{~b}(-65)$ & $0.02 \mathrm{c}(-84)$ & $0.82 \mathrm{~b}(-66)$ & $66.19 \mathrm{~b}(-64)$ & $5.28 \mathrm{~b}(-60)$ & 38.32 bc $(-35)$ & $35.58 \mathrm{c}$ \\
\hline $\mathrm{T}_{7}$ & 5.95 e $(-77)$ & $5.75 \mathrm{~cd}(-40)$ & $0.21 \mathrm{c}(-90)$ & $0.01 \mathrm{c}(-92)$ & 0.23 c (-91) & \begin{tabular}{|l|}
$29.04 \mathrm{bd}(-84)$ \\
\end{tabular} & $1.81 \mathrm{de}(-86)$ & $39.81 \mathrm{~b}(-32)$ & $32.36 \mathrm{c}$ \\
\hline $\mathrm{T}_{8}$ & $3.09 \mathrm{f}(-88)$ & 3.93 e $(-59)$ & 0.13 c (-95) & 0.01 c (-94) & 0.14 c $(-94)$ & 11.49 e $(-94)$ & $1.69 \mathrm{de}(-87)$ & $29.87 \mathrm{~d}(-49)$ & $42.46 \mathrm{bc}$ \\
\hline LSD & 1.70 & 0.92 & 0.29 & 0.05 & 0.33 & 10.15 & 1.68 & 2.92 & 24.82 \\
\hline
\end{tabular}

${ }^{1 /}$ Means with different letters differ significantly at 5\% level of probability. ${ }^{2 /}$ Figures given in parenthesis show percent change over control.

Table 3 - Influence of crop residues incorporated alone and in combination on photosynthetic pigments and total soluble phenolics in T. portulacastrum

\begin{tabular}{|c|c|c|c|c|c|}
\hline \multirow{2}{*}{ Treatment } & \multicolumn{4}{|c|}{ Pigment (mg g ${ }^{-1}$ fresh weight) } & \multirow{2}{*}{$\begin{array}{c}\text { Total soluble } \\
\text { phenolics } \\
\text { (mg g } \mathrm{m}^{-1} \text { fresh weight) }\end{array}$} \\
\hline & Chlorophyll a & Chlorophyll b & Chlor. a/Chlor. b & Total Chlorophyll & \\
\hline $\mathrm{T}_{1}$ & $3.16 \mathrm{a}^{\frac{1}{}}$ & $1.41 \mathrm{a}$ & 2.24 & $4.57 \mathrm{a}$ & $1.41 \mathrm{c}$ \\
\hline $\mathrm{T}_{2}$ & $2.55 \mathrm{ab}$ & $1.12 \mathrm{abc}$ & 2.28 & $3.67 \mathrm{ab}$ & $2.59 \mathrm{~b}$ \\
\hline $\mathrm{T}_{3}$ & $2.47 \mathrm{ab}$ & $1.26 \mathrm{ab}$ & 1.96 & $3.73 \mathrm{ab}$ & $2.54 \mathrm{~b}$ \\
\hline $\mathrm{T}_{4}$ & $1.38 \mathrm{c}$ & $0.63 \mathrm{~d}$ & 2.19 & $2.01 \mathrm{c}$ & $2.74 \mathrm{~b}$ \\
\hline $\mathrm{T}_{5}$ & $1.73 \mathrm{bc}$ & $0.84 \mathrm{~cd}$ & 2.06 & $2.57 \mathrm{bc}$ & $2.79 \mathrm{~b}$ \\
\hline $\mathrm{T}_{6}$ & $1.67 \mathrm{bc}$ & $0.92 \mathrm{bcd}$ & 1.82 & $2.59 \mathrm{bc}$ & $2.70 \mathrm{~b}$ \\
\hline $\mathrm{T}_{7}$ & $2.03 \mathrm{bc}$ & $0.88 \mathrm{bcd}$ & 2.31 & $2.91 \mathrm{bc}$ & $2.60 \mathrm{~b}$ \\
\hline $\mathrm{T}_{8}$ & $1.36 \mathrm{c}$ & $0.63 \mathrm{~d}$ & 2.16 & $1.99 \mathrm{c}$ & $3.40 \mathrm{a}$ \\
\hline LSD & 1.07 & 0.38 & - & 1.26 & 0.31 \\
\hline
\end{tabular}

${ }^{1 /}$ Means with different letters differ significantly at $5 \%$ level of probability 
the highest level (63\%) with incorporation of sorghum, sunflower and brassica residues each at $2 \mathrm{~g} \mathrm{~kg}^{-1}$ soil. However, sole incorporation of brassica residue at $6 \mathrm{~g} \mathrm{~kg}^{-1}$ soil had similar suppression (56\%) in total chlorophyll. There was a mixed response regarding ratio of chlorophyll a/b, and this seemed to be influenced by the amount of individual residues. Significantly higher phenolic contents were observed in horse purslane seedlings that were grown in soil amended with crop residues. A combination of all three crop residues produced highest water soluble phenolics (Table 3). Chlorophyll content in leaves of horse purslane decreased in soil amended with allelopathic crop residues (Table 3). Reduced chlorophyll content in allelochemical-treated plants has been reported elsewhere (Singh et al., 2010). Soybean plants treated with phenolic acids such as ferulic, p-coumaric, and vanillic acids exhibited reduced biomass due to lower chlorophyll content in leaves (Patterson, 1981). Allelochemicals released by decomposing crop residues might have inhibited chlorophyll by interfering with biosynthesis of photosynthetic pigments or enhancing their degradation or through the integration of both. Yang et al. (2002) investigated the effects of three phenolic acids on the concentration of chlorophyll and its three biosynthetic porphyrin precursor's proto, Mg-Proto and Pchlide. They argued that tested phenolic acids might have Mg-chelatase, an enzyme responsible for the conversion of Proto into $\mathrm{Mg}$-Proto as their major target. In contrast, allelochemical mediated suppression in the chlorophyll content from the trichomes of Parthenium hysterophorus was attributed to enhanced chlorophyll degradation (Kanchan \& Jayachandra, 1980). Reduction in chlorophyll was associated with higher total phenolics in horse purslane seedling (Figure 1). Allelochemical-mediated reduction in seedling photosynthetic pigments primarily due to phenolic acids has been reported (Inderjit \& Dakshini, 1992).

Mixed application of crop residues showed higher inhibition of horse purslane germination and seedling growth than their isolated treatments (Tables 1 and 2). It seems that apparently a combination of residues with variety of allelochemicals each

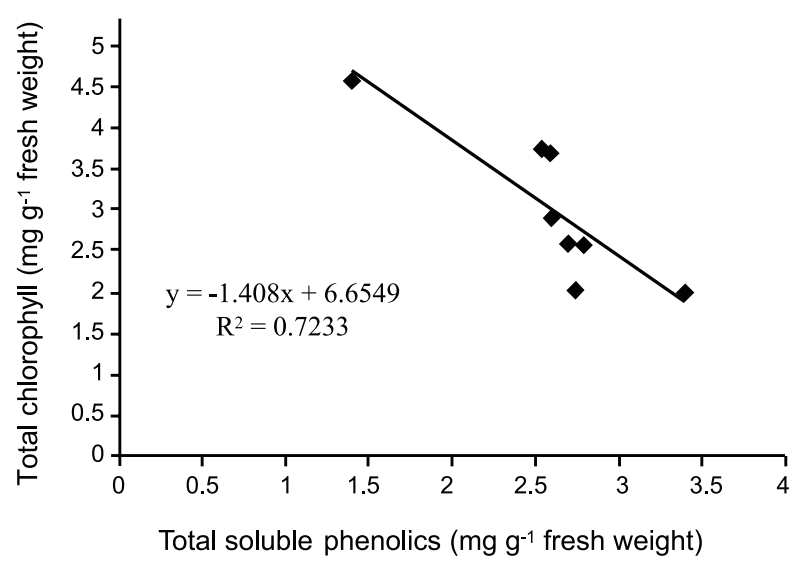

Figure 1 - Relationship between total soluble phenolics and total chlorophyll content in Trianthema portulacastrum.

having a different mode and site of action was more effective than application of individual crop residues (Jamil et al., 2009). This might had increased not only the number of susceptible sites but also the concentration and uptake of allelochemicals. A number of experiments have established that combinations of allelochemicals act additively or synergistically to inhibit plant growth (Duke \& Lydon, 1993; Einhelling, 1996).

Present work concluded that combined application of sorghum, sunflower and brassica residues have potential to suppress germination and seedling growth of horse purslane. Khanh et al. (2005) asserted the use of a combination of different crop plants may help control more weed species than a single crop material. Blum (1996) reported that mixtures of phenolic allelochemicals and other organics present in the substratum could cause inhibitory effects even though concentration of the individual allelochemicals is below the required level to cause an effect. These residues can be used as eco-friendly approach for management of this weed, provided phytotoxins entering into the soil encounter the early growth and development of horse purslane. Investigations may further be conducted to evaluate suppressive efficacy of such residues applied alone and in combination with each other under field conditions. Sorghum, sunflower and brassica crop allelopathy may also be evaluated in different crop rotations for managing the spread of horse purslane. 


\section{LITERATURE CITED}

ANJUM, T.; BAJWA, R. A. bioactive annuionone from sunflower leaves. Phytochemistry, v. 66, n. 16, p. 1919-1921, 2005.

ASSOCIATION OF OFFICIAL SEED ANALYSIS - ASOA. Seed vigor testing handbook. Springfield: 1983.

(Contribution, 32)

ASSOCIATION OF OFFICIAL SEED ANALYSIS - ASOA. Rules for testing seeds. J. Seed Technol., v. 12, n. 3, p. $1-112,1990$

BALYAN, R. S.; MALIK, R. K. Control of horse purslane (Trianthema portulacastrum) and barnyard grass (Echinochloa crus-gali) in mung bean (Vigna radiata). Weed Sci., v. 37, n. 5, p. 695-699, 1989

BATISH, D. R. et al. Phytotoxicity of sunflower residues against some summer season crops. J. Agron.Crop Sci., v. 188, n. 1, p. $19-24,2002$

BHOWMIK, P. C. Annual grass weeds control. Mass Weed Sci. Res. Results, v. 11, n. 1, p. 77-80, 1992.

BLUM, U. Allelopathic interactions involving phenolic acids. J. Nematol., v. 28, n. 3, p. 259-267, 1996

CHACON, J. C.; GLIESSMAN, S. R. Use of the non-weed concept in traditional tropical agroecosystems of southerneastern Mexico. Agroecosystems, v. 8, n. 1, p. 1-11, 1982.

CHEEMA, Z.A.; KHALIQ, A. Use of sorghum allelopathic properties to control weeds in irrigated wheat in a semi arid region of Punjab. Agric. Ecosyst. Environ., v. 79, n. 2-3, p. $105-112,2000$.

CHEEMA, Z. A. et al. Purple nutsedge management with allelopathic sorghum. Allelopathy J., v. 23, n. 2, p. 305-312, 2009.

DUKE, S. O.; LYDON, J. Natural phytotoxins as herbicides. In: DUKE, S. O.; MENN, J. J.; PLIMMER, J. R., (Eds.). Pest control with enhanced environmental safety. Washington, D.C., American Chemical Society, 1993. p. 111-121. (Symposium Series, 524)

DUKE, S. O. et al. Allelochemicals as herbicides. In: BONJOCH, N. P.; REIGOSA, M. J. (Eds.). EUROPEAN OECD ALLELOPATHY SYMPOSIUM: physiological aspects of allelopathy, 1., 2001. GAMESAL, 2001. p. 47-59.

EINHELLIG, F. A. Interactions involving allelopathy in cropping systems: Allelopathy in cropping systems.

Agron. J., v. 88, n. 6, p. 883-893, 1996.
ELLIS, R. A.; ROBERTS, E. H. The quantification of ageing and survival in orthodox seeds. Seed Sci. Technol., v. 9, p. 373-409, 1981.

FAROOQ, $M$. et al. Thermal hardening: a new seed vigor enhancing tool in rice. J. Integrative Plant Biol., v. 47, n. 2, p. 187-193, 2005.

FOY, C. L. How to make bioassays for allelopathy more relevant to field conditions with particular reference to cropland weeds. In: INDERJIT, R. K.; DAKSHINI, K.M.M.; FOY, C. L. (Eds.). Principles and practices in plant ecology: Allelochemical interactions. Boca Raton: CRC Press, 1999. p. 25-33.

GALLANDT, E. et al. Improving soil quality: implications for weed management. J. Crop Produc., v. 2, n. 1, p. 95-121, 1999.

GRICHER, W. J. Herbicide systems for control of horse purslane (Tianthenma portulacestrum L.), smellmelon (Cucumis melo L.) and palmer Amaranth (Amarauthus palmer) control in peanut. Peanut Sci., v. 35, n. 1, p. 38-42, 2008.

INDERJIT, R. K. Soils: environmental effect on allelochemical activity. Agron. J., v. 93, n. 1, p. 79-84, 2001

INDERJT, R. K.; DAKSHINI, K. M. M. Interference potential of Pluchea lanceolata (Asteraceae): growth and physiological responses of asparagus bean, Vigna unguiculata var. sesquipedalis. Am. J. Bot., v. 79, n. 9, p. 977-981, 1992.

JAMIL, M. et al. Alternative control of wild oat and canary grass in wheat fields by allelopathic plant water extracts. Agron. Sustain. Develop., v. 29, n. 3, p. 475-482. 2009.

JIMÉNEZ-OSORNIO, J. J.; GLIESSMAN, S. R Allelopathic interference in a wild mustard (Brassica campestris L.) and broccoli (Brassica oleracea L. var. italica) intercrop agroecosystems. In: WALLER, G. R. (Ed.). Allelochemicals: role in agriculture and forestry. Washington, D.C.: ACS, 1987. p. 262-274.

KANCHAN, S.D.; JAYA CHANDRA. Pollen allelopathy: a new phenomenon. New Phytol., v. 84, n. 4, p. 739-746, 1980 .

KHANH, T. D. et al. The exploitation of crop allelopathy in sustainable agricultural production. J. Agron.Crop Sci., v. 191, n. 3, p. 172-184, 2005.

LICHTENTHALER, H. K.; WELLBURN, A. Chlorophyll and carotenoids: pigments of photosynthetic bio-membranes. In: PACKER, L.; DOUCE, R. (Eds.). Methods in enzymology. San Diego: Academic Press, 1987. p. 350-382. 
MACIAS, F. A. et al. Bioactive terpinoids from sunflower leaves cv. Peredovick. Phytochemistry, v. 61, n. 6, p. 687-692, 2002.

NELSON, C. J. Allelopathy in cropping systems. Agron. J., v. 88 , n. 6, p. $991-996,1996$

NETZLY, D. H.; BUTLER, L. G. Roots of sorghum exude hydrophobic droplets containing biologically active components. Crop Sci., v. 26, n. 4, p. 775-780, 1986.

NORSWORTHY, J. K. et al. Weed suppression in Vigna unguiculata with a spring-seeded brassicaceae green manure Crop Protec., v. 24, n. 5, p. 441-447, 2005.

PATTERSON, D. T. Effects of allelochemicals on growth and physiological responses of soybean (Glycine max).

Weed Sci., v. 29, n. 1, p. 53-59, 1981.

PURVIS, C. E. et al. Selective regulation of germination and growth of annual weeds by crop residues. Weed Res., v. 25 , n. 6, p. $415-421,1985$.

RANDHIR, R.; SHETTY, K. Developmental stimulation of total phenolics and related antioxidant activity in light and dark germinated maize by natural elicitors. Process Biochem., v. 40, n. 5, p. 1721-1732, 2005.

SCHMIDT, S. K.; LEY, R. E. Microbial competition and soil structure limit the expression of phytochemicals in nature. In INDERJIT, R. K.; DAKSHINI, K.M.M. (Eds.). In: Allelopathy: organisms, processes and applications. Washington, DC: American Chemical Society, 1999. p. $339-351$.
SETHI, A.; MOHNOT, K. Allelopathic influence of leaf extracts of Trianthema portulacastrum on germination and growth of moth bean, Vigna aconitifollus. J. Current Biosci., v. 5 , n. 1, p. $61-63,1988$

SINGH, N. B. et al. Autotoxicity of maize and its mitigation by plant growth promoting rhizobacterium Paenibacillus ploymyxa. Allelopathy J., v. 25, n. 1, p. 195-204, 2010.

THORNE, R. L. Z. et al. Autotoxic effects of old and new wheat straw in conventional-tillage wheat soil. Bot. Bull. Academia Sinica, v. 31, n. 1, p. 35-39, 1990.

TOLLSTEN, L.; BERGSTROM, G. Headscape volatiles of whole plant and macerated plant parts of brassica and sinapis Phytochemistry, v. 27, n. 12, p. 4013-4018, 1988.

WESTON, L. A. Utilization of allelopathy for weed management in agro-ecosystems. Agron. J., v. 88, n. 6, p. $860-866,1996$.

WESTON, L. A. History and current trends in the use of allelopathy for weed management. Hortic. Technol., v. 15, n. 3 , p. $529-534,2005$.

WESTON, L. A.; DUKE, S. O. Weed and crop allelopathy. Critical Rev. Plant Sci., v. 22, n. 3/4, p. 367-389, 2003.

YANG, C. M. et al. Effects of three allelopathic phenolics on chlorophyll accumulation of rice (Oryza sativa) seedlings: I Inhibition of supply-orientation. Bot. Bull. Academia Sinica, v. 43, n. 4, p. 299-304, 2002.

XUAN, T. D. et al. Methods to determine allelopathic potential of crop plants for weed control. Allelopathy J. v. 13, n. 1, p. 149-164, 2004. 